\title{
POLITIK HUKUM ISLAM DI INDONESIA
}

\author{
Oleh: Muhsin Aseri*
}

Abstrak

Kajian ini dilator belakangi perjalanan panjang hukum Islam untuk menjadi hukum formal di Indonesia tidak sepi dari polemik, khususnya pergumulan hukum Islam dengan hukum Barat dan hukum Adat, banyak menuai dilema dalam kebijakan. Perseteruan antara politik dan hukum sangat kuat dalam supremasinya. Oleh karena itu kajian ini berupaya mendiskripsikan konsep tualisasi politik hukum Islam dan pemberlakuannya di Indonesia. Kajian ini menemukan bahwa konfigurasi politik senantiasa akan berpengaruh terhadap sifat /karakter produk hukum Islam yang dihasilkan. Posisi dan fungsi hukum Islam di Indonesia sangat terpengaruh atas politik hukum. Dan berlakunya hukum Islam di Indonesia sebagai refleksi kajian politik hukum Islam.

Kata Kunci: Politik, Hukum Islam, Indonesia

\section{A. Pendahuluan}

Hukum Islam untuk menjadi hukum formal di Indonesia, tidak sepi dari polemik, khususnya pergumulan antara hukum Islam dengan hukum Barat dan hukum Adat, banyak menuai dilema dalam kebijakan. Perseteruan antara politik dan hukum sangat kuat dalam supremasinya. Jika dilihat dari perkembangannya, terdapat tiga persimpangan dalam hukum Islam di Indonesia. Pertama, berasal dari kelompok yang menghendaki pemberlakuan hukum Islam di Indonesia untuk mengatur pemeluknya, disebut kelompok tradisional yakni, kelompok yang beranggapan bahwa agama mengatur semua aspek kehidupan, maka umat Islam harus mempraktekan aturan-aturan hukum Islam termasuk dalam kehidupan bernegara sekalipun. Kedua, kelompok moderat berasal

*Dosen tetap STAI Darul Ulum Kandangan

Jurnal Ilmiah Al QALAM, Vol. 9, No. 17, Januari-Juni 2016 
dari golongan yang menginginkan adanya keseragaman dan kesatuan hukum. Ketiga, kelompok sekuler yang menginginkan tidak berlakunya hukum Islam secara melembaga, ${ }^{1}$ kelompok ini beralasan bahwa agama hanya mengatur urusan individu dengan tuhannya yang berupa ibadah ritual, sama sekali tidak mengatur aspek sosial konkret, termasuk aturan hukum. Hubungan yang anta gonistik tersebut sangat kuat mempengaruhi kebijakan pemerintah, baik dalam penerapan maupun penyerapan hukum Islam.

Indonesia yang mayoritas penduduknya beragama Islam sudah tentu saja akan selalu menjadikan Islam sebagai sendi yang memegang peranan signifikan dalam berbagai segi kehidupan. Islam, dalam perspektif pemeluknya bukan sekedar doktrin ansich, ia menjadi nilai prinsip dan sumber motivasi yang khas. Oleh karena itu, hasrat umat Islam untuk memberlakukan syari'at (hukum Islam) di Indonesia selalu mengemuka dalam setiap tahapan ditanah air, terlebih pada era krisis multi dimensi, yang kemudian banyak memunculkan keinginan untuk kembali pada nilai-nilai alternatif yang berbasis Islam. $^{2}$ Tetapi kemudian, dalam upaya dan perjuangan implementasi syari'at, seperti sejarahnya, selalu saja tidak lepas dari hubungan kausalitas antara agama (Islam) dan negara yang senantiasa mengalami dinamika pasang surut konfigurasi politik dan hukum Islam yang berjalan berkelindan.

Pada dasarnya politik dan hukum Islam adalah dua sisi mata uang yang tidak dapat dipisahkan dalam suatu masyarakat Islam. Hukum Islam tanpa dukungan politik sulit diterapkan, begitu pula sebaliknya, politik yang mengabaikan hukum Islam akan mengakibatkan kekacauan

${ }^{1}$ Abdul Halim, Peradilan Agama dalam Politik Hukum di Indonesia (Jakarta: PT. Grasindo Persada, 2000), hal. XXII.

${ }^{2}$ M. Imadudin Rahmat, “Jalan Alternatif Syari'at Islam”dalam Tashwirul Afkar No. 12. Th. 2002, hal. 2-5. 
dalam tatanan bermasyarakat. ${ }^{3}$ Hal ini diyakini benar oleh mereka yang telah memiliki kesadaran hukum, sehingga mempraktekan dan memperjuangkan hukum Islam dalam sebuah negara yang mayoritas penduduknya beragama Islam, adalah suatu keharusan bagi umat Islam, baik melalui jalur legal-formal maupun jalan subtansial. Di Indonesia, implementasi, cita hukum, dan kesadaran hukum-mautidakmau-turut dibentuk oleh konfigurasi sosial- politik yang berkembang dalam masyarakatnya.

\section{B. Pengertian Politik Hukum Islam}

Politik hukum adalah suatu pernyataan kehendak penguasa negara mengenai hukum yang akan berlaku diwilayahnya, dan mengenai arah perkembangan hukum yang dibangun. ${ }^{4}$ Dapat pula diambil pengertian bahwa politik hukum adalah kebijakan hukum (legalpolicy) yang akan atau telah dilaksanakan secara nasional oleh pemerintah Indonesia, meliputi aspek-aspek hukum yang diperlukan dalam pembentukan hukum, yakni: Pertama, pembangunan hukum yang berintikan pembuatan hukum dan pembaharuan terhadap materi-materi hukum agar dapat sesuai dengan kebutuhan. Kedua, pelaksanaan ketentuan hukum yang telah ada, termasuk penegasan fungsi lembaga dan pembinaan para penegak hukum. ${ }^{5}$ Jadi, politik hukum adalah bagaimana hukum akan atau seharusnya dibuat dan ditentukan arahnya dalam kondisi politik nasional serta bagaimana hukum difungsikan.

Istilah politik hukum Islam (dalam bahasa Arab; al-Siyâsah alSyar'iyyah) merupakan aplikasi "maslahah mursalah", yaitu mengatur

3. Imadudin Rahmat, “Jalan Alternatif Syari'at Islam”dalam Tashwirul Afkar No. 12. Th. 2002, hal. XIII.

${ }^{4}$ Marzuki Wahid \& Rumadi,Fiqh Madzhab Negara: Kritik Atas Politik Hukum di Indonesia (Yogyakarta:LKiS, 2001), hal. 39.

5 Mahfud MD, Politik Hukum di Indonesia, cet.III (Jakarta: LP3ES, 2006), hal. 9. 
kesejahteraan manusia dengan hukum yang ketentuannya tidak termuat dalam syara'. 6 Sebagian ulama mendefinisikan politik hukum Islam sebagai perluasan peran penguasa untuk merealisasikan kemaslahatan manusia sepanjang hal tersebut tidak bertentangan dengan dasar-dasar agama. Sebagian lainnya memberikan pengertian yang lebih umum dari segi bahasa, yaitu mengatur kesejahteraan manusia sesuai dengan hukum. Yang jelas, sepanjang ada kemaslahatan artinya syari'ah telah ditegakkan. ${ }^{7}$ Prinsip inilah yang menjadikan hukum Islam tidak bersifat statis, melainkan meluas kesemua sisi kehidupan manusia baik secara individual maupun sosial.

Dalam perspektif politik hukum Islam, sistem hukum terbagi menjadi dua macam. Pertama, produk hukum yang dihasilkan oleh mujtahid fiqh, berdasarkan atas metodologi yang mereka ciptakan. Kedua, kebijakan para pakar politik dalam merealisasi kemaslahatan dalam menghadapi perkembangan zaman. Menurut para ahli, macam yang kedua ini dapat disesuaikan dengan mengutamakan kemaslahatan, sejauh tidak menyimpang dari batasan agama dan dasar-dasarnya sebagai totalitas. ${ }^{8}$

Demikian juga dengan produk hukum yang harus didasarkan pada hukum Islam, dengan tetap menyesuaikan situasi dan kondisi yang mengitarinya, termasuk dalam produk perundang-undangan.

Alasan lain, selain yang telah disebut diatas, adalah tugas umat untuk menciptakan ketertiban dimuka bumi, yakni tata tertib sosio-politis yang harus ditegakkan atas dasar etika yang sah dan viable. Studi ini mengambil pengertian bahwa politik hukum Islam adalah legal policy

\footnotetext{
${ }^{6}$ Abdul Wahab Khallaf, Politik Hukum Islam, alih bahasa Zainudin Adnan, (Yogyakarta: TiaraWacana, Mei 2005). Katapengantar, hal.v-vii.

${ }^{7}$ Abdul Wahab Khallaf, Politik Hukum Islam, alih bahasa Zainudin Adnan. hal, 13.

${ }^{8}$ Abdul Wahab Khallaf, Politik Hukum Islam, alih bahasa Zainudin Adnan. ,hal. 10.
} 
yang akan atau telah dilaksanakan pemerintah Indonesia dalam mengatur dan melindungi masyarakat Indonesia dengan dibentuknya undangundang serta aturan permanen bagi umat Islam melalui legislasi atau bentuk akomodasi politik lain.

\section{Konseptualisasi Politik Hukum Islam di Indonesia}

Untuk memahami politik hukum Islam di Indonesia, perlu diberikan uraian singkat tentang konsep dan ruang lingkup sekitar tema bahasan ini. Paling tidak ada tiga konsep yang harus dijelaskan: hukum Islam (yang dimaksud dalam tulisan ini), konfigurasi politik, dan karakter produk hukum.

\section{Hukum Islam}

Hukum Islam adalah hukum yang dibagun berdasarkan pemahaman manusia atas nasal-Qur'an maupun al-Sunnah untuk mengatur kehidupan manusia yang berlaku secara universal-relevan pada setiap zaman (waktu) dan tempat (ruang)-bagi semua orang Islam di mana pun, kapanpun, dan kebangsaan apapun.

Istilah hukum Islam, sebagaimana diketahui, adalah istilah khas Indonesia yang merupakan terjemahan dari al-fiqh al-Islâmŷ, atau dalam konteks tertentu disebut al-syari'a hal-Islâmiyah. Dalam literatur Barat istilah ini dikenal dengan idiom Islamic Law/Islamic Jurisprudence. ${ }^{9}$

Namun secara teknis, hukum Islam banyak dipakai untuk menggantikan istilah Syari'ah dan Figh. ${ }^{10}$

9 Said Agil Al-Munawar, Hukum Islam dan Pluralitas Sosial, (Jakarta: Penamadani, 2004), hal. 7. Kata Islamic Law dalam definisi yang lebih padat yaitu "keseluruhan khittâb Allah yang mengatur kehidupan muslim dalam setiap aspeknya", dari definisi ini hukum Islam identik dengan arti syari'at Islam

${ }^{10}$ Penjelasan detail mengenai sinonim dan derivasi kata hukum Islam, dapat dilihat dalam Ahmad Rofiq, Pembaharuan Hukum Islam di Indonesia, cet. I 
Dalam perjalanan sejarah hukum Islam, setidaknya ada empat macam produk pemikiran, yaitu kitab-kitab fiqih, fatwa-fatwa, keputusan-keputusan Pengadilan Agama, dan peraturan perundangundangan dinegeri-negeri muslim. Masing-masing produk pemikiran hukum itu memiliki ciri khas sendiri dan memerlukan pemikiran tersen diri pula. ${ }^{11}$ Jadi, objek kajian hukum Islam dalam tulisan ini ialah hukum atau aturan yang sesuai dengan ketentuan dasar agama Islam-yang mengandung norma moral dan norma hukum-untuk kemaslahatan manusia, sesuai dengan Maqoshid Syari'ah yang merupakan pesan utama sekaligus substansi hukum Islam. ${ }^{12}$

Keberlakuannya disahkan oleh negara menurut prosedur yang ditentukan oleh konstitusi atau aturan-aturan lain yang berlaku di negara Indonesia.

\section{Konfigurasi Politik}

Studi tentang politik hukum tidak hanya melihat hukum dari perspektif formal yang mengandung kebijakan-kebijakan dan rumusan resmi sebagai produk saja, tapi juga melihatnya dari latar belakang lahirnya legalpolicy itu sendiri. Konfigurasi politik diartikan sebagai susunan atau konstalasi kekuatan politik yang secara dikotomis dibagi atas dua konsep yang bertentangan secara diametral, yaitu konfigurasi politik demokratis dan konfigurasi

(Yogyakarta: Gama Media, 2001), hal. 13-24.

${ }^{11}$ Moh. Muhaimin, "Sosialisasi Kompilasi Hukum Islam di Indonesia (Inpres No. 1 Tahun 1991) ; Peranan Alumni Fakultas Syari'ah Khususnya Yang Berprofesi Sebagai Hakim" dalam jurnal Asy Syir'ah, No. 4 Th 1996, hlm. 44. Ditegaskan, bahwa saat ini umumnya masyarakat Islam di Indonesia memandang fiqih identik dengan hukum Islam, dan huku Islam dipandang Identik dengan hukum Tuhan. Sebagai akibatnya, fiqih dianggap sebagai aturan Tuhan itu sendiri.

${ }^{12}$ Hukum Islam dalam konteks Indonesia yaitu, hukum yang bersumber dari alQur'an dan Sunnah yang telah dipadukan dengan pandangan dan kenyataan hidup masyarakat Indonesia.

Jurnal Ilmiah Al QALAM, Vol. 9, No. 17, Januari-Juni 2016 
politik otoriter. Pengertian dan indikator variabel bebas ini adalah:

a. Konfigurasi politik demokratis adalah sistem politik yang memberikan peluang bagi berperannya potensi masyarakat secara maksimal untuk turutaktif menentukan kebijakan umum (negara). Dalam konfigurasi yang demikian, pemerintah tidak lebih merupakan "Komite" yang harus me-laksanakan kehendak masyarakatnya, yang dirumuskan secara demokratis. Selain itu, partai politik berfungsi secara aktif dan proporsional melalui lembaga perwakilan, dan lebih menentukan dalam pembuatan kebijakan negara; rakyat memiliki kebebasan untuk memberikan kritik pada pemerintah (dunia pers dapat melaksanakan fungsinyadengan bebas tanpa ancaman pembreidelan). Karena dalam negara yang menganut sistem demokrasi (konfigurasi politik demokratis), hidup dan berkembangnya organisasi menjadi penting dan relatif otonom.

b. Konfigurasi politik otoriter adalah sistem politik yang menempatkan pemerintah pada posisi dominan dengan sifat yang intervensionis dalam penentuan dan pelaksanaan kebijakan negara. Potensi dan aspirasi masyarakat tidak teragregasi ${ }^{13}$ dan terartikulasi secara proporsional. Bahkan, akibat peran pemerintah yang sangat dominan, badan perwakilan rakyat dan partai politik tidak berfungsi dengan baik, dan hanya merupakan alatjustifikasi (rubberstamps) atas kehendak pemerintah; rakyat tunduk dan tidak dapat mengkritik pemerintah (pers tidak memiliki kebebasan, senantiasa berada dibawah kontrol pemerintahdan bayang-bayang pembreidelan).

${ }^{13}$ Aspirasi masyarakat (umatIslam) tidak terhimpun / terakomodasi. 


\section{Karakter Produk Hukum}

Karakter produk hukum dalam tulisan ini disamakan dengan sifat atau watak produk hukum. Hal ini sebenarnya dapat dilihat dari berbagai sudut teoritis. Misalnya, dari segi-segi tentanghukum dapat dikemukakan bahwa hukum mempunyai sifat итит (peraturan hukum tidak ditujukan kepada seseorang dan tidak akan kehilangan kekuasaannya jika telah berlaku terhadap suatu peristiwa konkret), abstrak (mengatur hal-hal yang belum terikat dengan kasus-kasus konkret), selain itu ada yang mengidentifikasi hukum dengan sifat imperatif dan fakultatif. ${ }^{14}$

Dalam studi ini kajian difokuskan pada sifat atau karakter produk hukum yang dibagi secara dikotomi santara hukum otonom dan hukum menindas serta hukum responsif dan hukum ortodoks. Kedua dikotomi tersebut kemudian dikelompokan menjadi satu dikotomi yaitu hukum responsive/ otonom /populistik dan hukum konservatif /ortodoks /elitis.

a. Produk hukum responsif / otonom / populistik adalah produk hukum yang karakternya mencerminkan tuntutan-tuntutan baik individu maupun kelompok sosial didalam masyarakat, ${ }^{15}$ sehingga lebih mampu mencerminkan rasa keadilan dalam masyarakat. Proses pembuatan hukum responsif ini mengundang secara terbuka partisipasi dan aspirasi masyarakat, termasuk lembaga peradilan. Hukum diberi fungsi sebagai alat pelaksana bagi kehendak masyarakat. Oleh karenanya ia menggambarkan muatan (isi) yang aspiratif; sedangkan rumusan hukumnya dibuat cukup

\footnotetext{
${ }^{14}$ Mahfud MD, Politik Hukum di Indonesia, hal. 19.

${ }^{15}$ Dalam makalah ini yang dimaksud masyarakat secara spesifik ialah umat Islam Indonesia.
}

Jurnal Ilmiah Al QALAM, Vol. 9, No. 17, Januari-Juni 2016 
rinci, sehinggga tidak terbuka untuk dapat diinterpretasi berdasarkan kehendak dan visi pemerintah sendiri.

b. Produk hukum konservatif / ortodoks / elitis adalah produk hukum yang karakternya mencerminkan visi politik pemerintah, pemegang kekuasaan dominan, sehingga pembuatannya tidak mengundang partisipasi dan aspirasi masyarakat secara sunguhsungguh. Jika prosedur ini ada, biasanya lebih bersifat formalistik. Dalam produk yang demikian, hukum biasanya diberi sifat "positivis instrumentalis " atau menjadi alat bagi pelaksanaan ideologi dan program pemerintah. Rumusan materi hukumnya biasanya bersifat pokok-pokok saja sehingga dapat diinterpretasi oleh pemerintah menurut visi dan kehendak sendiri dengan berbagai peraturan pelaksanaan.

\section{Hukum Sebagai Produk Politik}

Asumsi bahwa hukum merupakan produk politik menghantarkan penulis pada hipotesis bahwa konfigurasi politik tertentu akan melahirkan karakter produk hukum tertentu pula. Secara dikotomis konfigurasi politik dibagi atas konfigurasi demokratis dan konfigurasi non-demokratis. Sedangkan variabel produk hukum dibagi atas produk hukum yang berkarakter responsif atau otonom dan produk hukum yang berkaraker ortodoks / konservatif atau menindas. ${ }^{16}$

Aksioma ini tidak terlepas dari pendapat kalangan ahli hukum mengenai hubungan antara politik dan hukum. Setidaknya ada dua golongan yang mengkaji hal ini. Pertama, kaum idealis yang berdiri pada sudut dassollen yang mengatakan bahwa hukum harus mampu

${ }^{16}$ Mahfud MD, Pergulatan Politik dan Hukum di Indonesia, cet. I (Yogyakarta: Gama Media, 1999), hal. 6-7.

Jurnal Ilmiah Al QALAM, Vol. 9, No. 17, Januari-Juni 2016 
mengendalikan dan merekayasa masyarakatnya, termasuk dalam kehidupan politik. Kedua, kaum realis yang berdiri pada pandangan das sein. Mereka beranggapan bahwa hukum selalu berkembang sesuai dengan perkembangan masyarakatnya. Artinya, hukum berada pada posisi dependent variable bagi keadaan diluarnya, terutama keadaan politik.

Memang, di dalam kenyataannya hukum itu lahir sebagai refleksi dari konfigurasi politik yang melatarinya. Dengan katalain, kalimat-kalimat yang ada dalam aturan hukum itu tidak lain merupakan kristalisasi dari kehendak-kehendak politik yang saling bersaingan. Dalam kenyataan empirik, politik sangat menentukan proses kelahiran dan bekerjanya hukum. Satjipto Rahar djo mengemukakan bahwa kalau kita melihat hubungan antara subsistem politik dan subsistem hukum, tampak bahwa politik memiliki konsentrasi energi yang lebih besarketimbang hukum, sehingga hukum selalu berada pada posisi yang lemah. ${ }^{17}$

\section{Berlakunya Hukum Islam di Indonesia}

Dari sudut historis dan yuridis formal, keberadaan negara Republik Indonesia adalah sebuah negara yang pernah dijajah oleh Belanda, Inggris dan Jepang. Masing-masing membawa jenis hukum dan selang waktu yang berbeda-beda, dan karenanya telah dan akan memberikan implikasi yang berbeda pula. Dari sinilah kita akan dapat memahami adanya pluralitas sistem hukum yang berlaku di Indonesia sebagai sebuah konsekuensi. ${ }^{18}$ Hukum Islam sebagai bagian yang tak terpisahkan dari

${ }^{17}$ Satjipto Rahardjo,Beberapa Pemikiran Tentang Ancangan Antar Disiplin dalam Pembinaan Hukum Nasional (Bandung: SinarBaru,1985), hal.71.

${ }^{18}$ A. Qodri Azizy, Ekletisisme Hukum Nasional; Kompetisi Antara Hukum Islam dan Hukum Umum, (Yogyakarta: Gama Media, 2002), hal. 109.

Jurnal Ilmiah Al QALAM, Vol. 9, No. 17, Januari-Juni 2016 
ajaran agama (Islam) masuk dan menjadi bagian dari norma masyarakat sejak masuknya ajaran Islam itu sendiri, yakni mulai abad 1 Hijriah atau abad 7-8 Miladiyah. " Hukum Agama ini datang ke Indonesia bersamaan dengan hadirnya agama ". ${ }^{19}$ Keyakinan ini lah yang menjadikan hukum Islam berlaku mengatur dalam kehidupan masyarakat Indonesia. ${ }^{20}$

Sejarah berlakunya hukum Islam di Indonesia sebelum kemerdekaan dapat dilihat dari dua periode: pertama, penerimaan hukum Islam sepenuhnya, dan kedua, periode penerimaan hukum Islam oleh hukum Adat. Periode penerimaan hukum Islam sepenuhnya disebut dengan teori Receptie in Complexu, sedangkan periode penerimaan hukum Islam oleh hukum Adat disebut teori Receptie. ${ }^{21}$

Untuk menurut sejarah mulai berlakunya hingga eksistensi hukum Islam dalam dinamika kehidupan masyarakat Indonesia, sejarah hukum Islam dapat dilihat melalui klasifikasi teori yang pernah dikemukakan oleh para ahli hukum sebagai berikut:

\section{Teori Receptiein Complexu}

Teori hukum ini diperkenalkan oleh Van Den Berg dan dipraktekan pada masa Kolonial. Teori ini menyatakan bahwa semua

\footnotetext{
${ }^{19}$ A. Qodri Azizy, Ekletisisme Hukum Nasional; Kompetisi Antara Hukum Islam dan Hukum Umum., hal. 110.

${ }^{20}$ Hukum Islam di sini diartikan dengan: sebagian Syari'at Islam, yang dalam Ilmu fiqih termasuk dalam bidang mu'amalah, yang pelaksanaannya berbentuk tindakan hukum transaksi hukum antar mukallaf (subjek hukum), yang pada keadaan tertentu memerlukan campur tangan penguasa, misalnya penyelesaian sengketa. Lihat, Zainal Ahmad Noeh, "Keputusan Jawa Sebagai Sumber Sejarah Perkembangan Hukum Islam" dalam Amrullah Ahmad [et.al.], Dimensi Hukum Islam dalam Sistem Hukum Nasional; Mengenang 65 Tahun Prof. Dr. H. Bustanul Arifin, S.H., cet.I (Jakarta: Gema Insani Press, 1996), hal. 71-80.

${ }^{21}$ Lihat, Said Agil Husin Al-Munawar, Hukum Islam dan Pluralitas Sosial, hlm 11. Bandingkan dengan A. Hamid S. Attamimi, "Kedudukan Kompilasi Hukum Islam dalam Sistem Hukum Nasional; Tinjauan dari Sudut Teori Perundang-undangan Indonesia, dalam Amrullah Ahmad (et.al), Dimensi Hukum Islam, hal. 151.
}

Jurnal Ilmiah Al QALAM, Vol. 9, No. 17, Januari-Juni 2016 
sanksi hukum adat tunduk kepada sanksi yang diberlakukan dalam hukum Islam. Hukum Adat tidak akan dipakai jika bertentangan dengan hukum Islam. Hukum Adat berada dibawah hukum Islam, sedangkan hukum Islam sendiri sejajar dengan hukum positif.

Teori ini berlaku sejak pemerintah Kolonial memberlakukan hukum Islam, khususnya hukum perkawinan dan hukum waris, yang kemudian disebut dengan hukum kekeluargaan. Untuk menjamin pelaksanaan hukum tersebut, pemerintah Kolonial Belanda mengeluarkan peraturan Resolutieder Indische Regeering tanggal 25 Mei 1760, yang kemudian dikenal dengan Compendium Freijer. Dalam Regeering-Reglement (RR) tahun 1885, pasal 75, dinyatakan bahwa: oleh hakim Indonesia, hendaknya diberlakukan undangundang agama (Gods dienstige Wetter). ${ }^{22}$

2. Teori Receptie

Berkebalikan dari teori pertama, teori Receptie ini menyatakan bahwa hukum yang berlaku bagi orang Islam adalah hukum Adat mereka masing-masing. Hukum Islam berada dibawah hukum Adat, dan hukum Adat berdiri sejajar dengan hukum positif. ${ }^{23}$ Teori ini dikembangkan oleh Snouck Hurgronje (orientalis Belanda) setelah melakukan penelitian di berbagai daerah di Tanah Air. Ia menyimpulkan bahwa hukum Islam tidak dapat berlaku dalam masyarakat muslim kecuali jika diakui oleh hukum Adat setempat. Politik hukum ini bermuatan divideet impera yang bertujuan menghambat (menghentikan) meluasnya hukum Islam. Fungsinya

${ }^{22}$ Said Agil Husin Al-Munawar, HukumIslam dan Pluralitas Sosial, hal. 11. Lihat juga, Khoiruddin Nasution, "Kelahiran dan Perkembangan Peradilan Agama: Studi Sejarah Masa Belanda,"dalam Marzuki Wahid (et.al.), Fakultas Syari'ah Menatap Masa Depan, hal, 35-55.

${ }^{23}$ Dalam teori ini hukumAdat-lah yang menentukan ada tidaknya hukum Islam.

Jurnal Ilmiah Al QALAM, Vol. 9, No. 17, Januari-Juni 2016 
selain sebagai konsep tandingan dari teori pertama, sekaligus mendukung politik pecah-belah Kolonial Belanda.

Tertuang melalui Indische Stats regeling (IS) yang diundangkan dalam Stbl. 1929. 212, disebutkan bahwa hukum Islam dicabut dari tata hukum Hindia Belanda. Pasal 134 ayat (2) IS tahun 1929 itu berbunyi: "Dalam hal terjadi perkara perdataan tara sesama orang Islam, akan diselesaikan oleh hakim agama apa bila hukum Adat mereka menghendakinya dan sejauh itu tidak ditentukan lain dengan ordonansi." Selanjutnya, pada tahun 1937 pemerintah Hindia Belanda mengemukakan gagasan bahwa Pengadilan Agama yang mengadili masalah Kewarisan sejak tahun 1882 dialihkan menjadi wewenang Pengadilan Negeri, Melalui Stbl 177 : 116, dicabutlah wewenang Pengadilan Agama dengan alasan bahwa hukum waris belum sepenuhnya diterima oleh hukum adat. ${ }^{24}$

Perkembangan berikutnya, muncul teori-teori serupa pada jaman kemerdekaan, hukum Islam pun melewati dua fase. Fase pertama, hukum Islam sebagai sumber persuasif dalam konteks hukum konstitusi, yaitu sumber hukum yang baru diterima apabila diyakini. Dalam konteks hukum Islam, Piagam Jakarta sebagai salah satu hasil sidang BPUPKI merupakan sumber persuasif. Fase kedua, hukum Islam baru menjadi sumber otoritatif dalam ketatanegaraan ketika Dekrit Presiden. 5 Juli 1959 mengakui bahwa Piagam Jakarta menjiwai UUD $1945 .^{25}$

Keduanya berfungsi sebagai counter atas teori-teori masa Kolonial. Kedua teori ini muncul setelah Indonesia merdeka dan

${ }^{24}$ Said Agil Husin Al-Munawar, Hukum Islam dan Pluralitas Sosial, hal. 11-12.

25 Ismail Sunny, "Kedudukan Hukum Islam dalam Sistem Ketatanegaraan Indonesia, "dalam Amrullah Ahmad (et.al), Dimensi Hukum Islam, hal. 133-134. 
Muhsin Aseri: Politik Hukum Islam Di Indonesia

Pancasila beserta UUD 1945 telah ditetapkan sebagai sumber hukum. ${ }^{26}$

3. Teori Receptiea Contrario atau Receptie Exit

Teori Receptiea Contrario atau Receptie Exit adalah teori yang menyatakan bahwa hukum Adat berlaku kalau tidak bertentangan dengan hukum Islam. Hukum Adat yang tidak sejalan dengan ketentuan hukum Islam harus dikeluarkan, ditolak atau dilawan. ${ }^{27}$

Hukum Islam berada dalam posisi berdiri sejajar dengan sistem hukum lainnya. Teori ini didukung oleh Undang-Undang (UU) No. 1 / 1951 yang menyatakan tentang kemungkinan terciptanya satu kesatuan sistem hukum yang sama di Indonesia. Misalnya, dengan melakukan kodifikasi atau unifikasi hukum dengan mempertimbangkan kesadaran yang berkembang dalam masyarakat.

\section{Teori Eksistensi}

Teori ini dikemukakan oleh Ichtiarto SA untuk mempertegas dan mengeksplisitkan makna Receptie a Contrario dalam hubungannya dengan hukum nasional. Teori eksistensi ini mengokohkan keberadaan hukum Islam dalam hukum nasional. Menurutnya, hukum Islam : a) Ada (exist) sebagai bagian integral dari hukum nasional; b) Ada (exist) dalam arti, dengan kemandirian dan kekuatan wibawanya, ia di akui sebagai hukum nasional dan diberi status sebagai hukum nasional; c) Ada (exist) dalam arti norma hukum Islam sebagai penyaring bahan- bahan hukum nasional ;d)

${ }^{26}$ Lihat Marzuki Wahid \& Rumadi, Fiqh Madzhab Negara, hal. 84.

${ }^{27}$ Keterangan lebih detail lihat, Ahmad Rofiq, Hukum Islam di Indonesia, cet.4, (Jakarta: PT. Raja Grafindo Persada, 2000), hlm. 13-22. dan, Lutfi Assaukanie, "PositivisasiSyariat Islam"dalam Kurniawan Zein (ed.), Syariat Islam Yes Syariat Islam No: Dilema Piagam Jakarta dalam Amandemen UUD 1945, ( Jakarta: Paramadina, 2001), hal, 155-156. Bandingkan dengan Mahsun Fuad, Hukum Islam di Indonesia: Dari Nalar Partisipatoris Hingga Emansipatoris, cet. (Yogyakarta: LKiS, 2004), hal. 55-56

Jurnal Ilmiah Al QALAM, Vol. 9, No. 17, Januari-Juni 2016 
Ada (exist) sebagai bahan utama dan sumber utama hukum nasional. ${ }^{28}$

Gejala yang umum terjadi di negara-negara yang baru merdeka adalah munculnya kehendak untuk menghapus hukum yang diwariskan oleh penjajah. Begitu pula hukum warisan Kolonial di Indonesia hendak diganti dengan hukum yang dianggap cocok dengan alam kemerdekaan yang digali dari nilai-nilai yang hidup di dalam masyarakat dengan harapan hukum penggantinya itu mampu menampung dan mengikuti perubahan yang dialami oleh masyarakat dalam negara tersebut. Selain itu, terdapat kehendak dan usaha untuk memfungsikan hukum sebagai pengendali masyarakat (social control) sekaligus sebagai sarana rekayasa masyarakat (asatoolof social engineering). Hukum macam ini dipandang sebagai konkretisasi nilai yang dianut oleh masyarakat, yang mampu menampung pengembangan masyarakat selaras dengan tututan

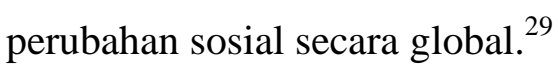

\section{E. Kesimpulan}

Di Indonesia konfigurasi politik cukup berpengaruh terhadap sifat / karakter produk hukum Islam yang dihasilkan. Posisi dan fungsi hukum Islam dalam pembangunan hukum nasional sangat terpengaruh atas politik hukum Islam. Politik memiliki konsentrasi energi yang lebih besar ketimbang hukum, sehingga hukum selalu berada pada posisi yang lemah.

Berlakunya hukum Islam di Indonesia sebagai refleksi kajian politik hukum Islam sebelum merdeka dan sesudah merdeka. Berlakunya hukum

${ }^{28}$ Ensiklopedi Hukum Islam, Abdul Aziz Dahlan [et.al.], cet. I ( Jakarta: Ichtar Baru Van Hoeve, 1996), III: 713., dalam Ichtiarto SA, Hukum Islam dan Hukum Nasional (Jakarta: In-Hill Co, 1990), hal. 86-87., dan lihat dalam, Said Agil Husin Al-Munawar, Hukum Islam dan Pluralitas Sosial, hal.14

${ }^{29}$ Cik Hasan Bisri, Peradilan Agamadi Indonesia, cet. II (Jakarta: Raja Grafindo Persada, 1998), hal. 79. 
Muhsin Aseri: Politik Hukum Islam Di Indonesia

Islam sebelum kemerdekaan dapat dilihat dari dua periode: penerimaan hukum Islam sepenuhnya disebutteori Receptie in Complexu, dan penerimaan hukum Islam oleh hukum Adat disebut teori Receptie. Padajaman kemerdekaan, hukum Islam pun melewati duafase. Fase pertama, hukum Islam sebagai sumber persuasif dalam konteks hukum konstitusi, yaitu sumber hukum yang baru diterima apabila diyakini. Fase kedua, hukum Islam baru menjadi sumber otoritatif dalam ketatanegaraan ketika Dekrit Presiden 5 Juli 1959 mengakui bahwa Piagam Jakarta menjiwai UUD 1945. 
Muhsin Aseri: Politik Hukum Islam Di Indonesia

\section{DAFTAR PUSTAKA}

Al-Munawar, Said Agil, Hukum Islam dan Pluralitas Sosial, cet. I, Jakarta: Penamadani, 2004

Ahmad, Amrullah, [et.al], Dimensi Hukum Islam dalam Sistem Hukum Nasioanal; Mengenang 65 Tahun Prof. Dr. H. Bustanul Arifin, Jakarta: Gema Insani Press, 1996

Abdullah Ahmed An-Naim, Dekontruksi Syari'ah: Wacana Kebebasan Sipil, HAM dan, Hubungan Internasional, Penerjemah: Ahmad Suaedy dan Amiruddin ar-Rany., LKiS, Yogyakarta, 1990

Amin Abdullah, Paradigma Alternatif Pengembangan Ushul Fiqh dan Dampaknya pada Fiqh Kontemporer, dalam Mazhab Jogja: Menggagas Paradigma Ushul Fiqh Kontemporer,Ar-Ruz, 2002

Anshari, Endang Saifuddin, Piagam Jakarta 22 Juni 1945: Sebuah Konsensus Nasional tentang Dasar Negara Republik Indonesia (1945-1959), Jakarta: Gema Insani Press, 1997

Amal, Taufik Adnan dan Samsu Rizal Pangabean, Politik Syari'at Islam; dari Indonesia hingga Nigeria, Jakarta: Pustaka Alvabet, Desember 2004 , cet. I.

Burhanudin [ed.], Syariat Islam Pandangan Muslim Liberal, Jakarta: JIL atas kerjasama dengan The Asia Foundation, 2003

Bisri, Cik Hasan, Peradilan Agama di Indonesia, cet. II, Jakarta: RajaGrafindo Persada, 1998

Departemen Agama Republik Indonesia, Al-Qur'an dan Terjemahnya, Surabaya: Tri Karya Surabaya, 2004

Daud Ali, Momammad, Hukum Islam dan Peradilan Agama, cet. I, Jakarta:

PT. Raja Grafindo Persada, 1977

Fuad, Mahsun, Hukum Islam Indonesia: Dari Nalar Partisipatoris Hingga Emansipatoris, Yogyakarta: LKiS, 2005

Jurnal Ilmiah Al QALAM, Vol. 9, No. 17, Januari-Juni 2016 
Muhsin Aseri: Politik Hukum Islam Di Indonesia

Halim, Abdul, Peradilan Agama dalam Politik Hukum di Indonesia, cet. I, Jakarta: PT. RajaGrafindo Persada, 2000

Ichtiarto, SA, Hukum Islam dan Hukum Nasional, Jakarta: In-Hill-Co, 2005

Khallaf, Abdul Wahab, Politik Hukum Islam, terj. Zainudin Adnan, cet II, Yogyakarta: Tiara Wacana.

Marzuki Wahid \& Rumadi, Fiqih Madzhab Negara; Kritik Atas Politik Hukum Islam di Indonesia, Yogyakarta: LKiS, 2001

Rofiq, Ahmad, Pembaharuan Hukum Islam di Indonesia, Yogyakrta: Gama Media, 2001

--------- , Hukum Islam di Indonesia, cet. IV, Jakarta: Raja Grafindo

Persada, 2000

Rahardjo, Satjipto, Beberapa Pemikiran Tentang Ancangan Antar Disiplin Dalam PembinaanHukum Nasional, Bandung: SinarBaru, 1985

Sumitro, Warkum, Perkembangan Hukum Islam di Tengah Dinamika Sosial Politik di Indonesia, Malang: Banyu Media, 2005

Qodri Azizy, A, Ekletisisme Hukum Nsional; Kompetisi antara Hukum Islam danHukum Umum, cet. I, Yogyakarta: Gama Media, 2002

Hadi, Sutrisno, Metodologi Research, Yogyakarta: Andi Offset. Joeniarto, , 1990

Mahfud MD, Moh, Politik Hukum Islam di Indonesia, Jakarta: Pustaka LP3ES, 2006 cet. III.

---------------, Pergulatan Politik dan Hukum di Indonesia,

Yogyakarta: Gama Media, Maret 1999

Syamsul Anwar, Pengembangan Metode Penelitian Hukum Islam, dalam Mazhab Jogja: Menggagas Paradigma Ushul Figh kontemporer, ArRuzz, Yogyakarta, , 2002

Taupik Adnan Amal, Islam dan Tantangan modernitas, studi atas pemikiran Hukum Fazlur Rahman, Mizan: Bandung, 1989

Jurnal Ilmiah Al QALAM, Vol. 9, No. 17, Januari-Juni 2016 
Muhsin Aseri: Politik Hukum Islam Di Indonesia

Zein Kurniawan (ed.), Syariat Islam Yes Syariat Islam No: Dilema Piagam Jakarta dalam Amandemen UUD 1945, Jakarta: Paramadina, , 2001 